\title{
Alive memories
}

\author{
HILTON F. JAPYASSÚ* \\ Universidade Federal da Bahia
}

This issue is devoted to the memory of César Ades, one of the founders of Ethology in Brazil, and I would like to open it with a short narrative. Stories were very important for César, the professor. They were ever present in his lectures, constituting a teaching style for this man, born as he was within an Arabic Sherazade tradition of stories that we live by.

At that time, an undeciphered, nonspecific desire prompted César to regular round walks through the university corridors, excitedly running back and forth, with his usually enthusiastic eyes now filled with anxiety. This was happening for a while when, one evening, he grasped my arm and dragged me to have a coffee, with a kind of urgency and electricity in the air. Walking and talking, babbling that we have much to offer, that we should have a vehicle in order to run faster, to gather people, put things together, throwing phrases to the wind. It took me a while to understand, from his disconnected and loud thoughts, that he was not trying to convince me to buy the last sports car model to impress people in an all night long party, but that he was instead up to a much more difficult and enduring task: he was dreaming about a communication vehicle for Brazilian ethology. I honestly tried to put him down to reason, for running a scientific journal is such a heavy enterprise, that needs a team of editors, a staff to run everyday jobs, a myriad of connections to attract good authors, but it was all in vain. He dismissed all my arguments with his usual ability to build up visions. He had already decided to create a community of writers and readers of ethology, he was already committed to the plan of communicating to everyone the good science he saw in national and Latin American meetings. César imagined a vehicle not only for specialized scientific readers, but for educated people in general. He was already on the

* Departament of Zoology, Institute of Biology, Federal University of Bahia, Rua Barão de Jeremoabo, s/n, Ondina University Campus, Salvador - BA / 40170-290. E-mail: japyassu@ufba.br handle to transform his dream in an engine of ideas. And this was how Revista de Etologia was born.

This special edition comes with a flavor of César's ideas. We have succeeded to gather, in one publication, contributions of his own, contributions inspired by his always open-minded, involving and compassionate conversations, contributions of long standing partners and of generations of young students, as well as a bit of history, in order to put things on its right places and times.

The themes discussed in this issue are almost as diverse as César's career (founders have the privilege of working successfully in many diverging directions). We start with a historical tessiture of places and times and unifying themes (Otta, 2012), including a fine blend of ethological observation with experimental manipulation of learning rats, under a neuroscientific approach (Bueno et al, 2012) - a good example of the kind of interdisciplinary thinking that César tried to put forward. The ecological embeddedness of learning was also on the core of César's concerns, and this tradition appears in many contributions to this issue: first, in a paper focused on fitness related-components of learning in fruit flies (Cresoni-Pereira et al, 2012); two other contributions on this theme deal with one of the most cherished animal models for César - spiders. One paper brings observations within natural history to try to cognitively understand impressive abilities that allow a tiny carnivore to eat a much bigger, dangerous carnivore (Silveira \& Japyassú, 2012). Another paper shows the impact of experience in changing a behavior that is usually taken for automatic in these animals: the weaving an orb web (Nogueira \& Ades, 2012). Communication was another core concern of César's, and an interesting evo-devo proposal for guinea pig whistles represents this area of study (Corat et al, 2012). Finally, a latecomer in César's ever growing scientific agenda: the imports of behavioral studies to the conservation and environmental enrichment of captive animals (Vasconcellos \& Ades, 2012).

There should be more, we agree, if we were to honor properly César's lively connectedness to 
the study of behavior. But one should know that, as Borges in his enchanted infinite labyrinth, there is always another labyrinth behind each door one finds along the multifarious alleys of a great man's mind. In order to be at least helpful in such an intricate geography, a map should always be smaller - in this case, much smaller than the real life it stands for. So, each contribution in this issue should perhaps be understood as a small entry, a key to the creativity engine of this man, a fractal mirror where one can for some time see through the eyes and heart of this brilliant scientific, integrative, and communicative mind.

\section{References}

Bueno,J.L.O., Bernardes, E. deF.\&Judice-Daher,D. M. The reinforcement omission effect on behavioral repertoire of rats with lesions in the basolateral complex and central nucleus of the amygdala. Revista de Etologia $11(1), 11-22$.

Corat, C., Tarallo, R. C. R. B., Savalli, C., Tokumaru, R. S., Monticelli, P. F. \& Ades, C. The whistles of the Guinea pig: an evo-devo proposal. Revista de Etologia $11(1), 46-55$.
Cresoni-Pereira, C., Medeiros-Santana, L. \& Zucoloto, F. S. Associative Learning in Anastrepha obliqua (Diptera, Tephritidae) Wild Females and Males of Different Ages and Nutritional States. Revista de Etologia 11(1), 68-78.

Nogueira, S. S. da C. \& Ades, C. Evidence of learning in the web construction of the spider Argiope argentata (Araneae: Araneidae). Revista de Etologia 11(1), 23-36.

Otta, E. (2013). In Memory of César Ades (1943-2012): The Legacy of Psycho-Ethology. Revista de Etologia 11(1), 3-10.

Silveira, M. C. \& Japyassú, H. F. Notes on the behavior of the kleptoparasitic spider Argyrodes elevatus (Theridiidae, Araneae). Revista de Etologia 11(1), 56-67.

Vasconcellos, A. da S. \& Ades, C. Possible limits and advances of environmental enrichment for wild animals. Revista de Etologia 11(1), 37-45. 